\title{
GAMBARAN HASIL CT SCAN KEPALA PADA PENDERITA NYERI KEPALA DI BAGIAN RADIOLOGI FK UNSRAT/SMF RADIOLOGI BLU RSUP PROF. Dr. R. D. KANDOU MANADO PERIODE 1 JANUARI-31 DESEMBER 2011
}

\author{
${ }^{1}$ Muhammad Nugraha Madja \\ ${ }^{2}$ Ramli Hadji Ali \\ ${ }^{2}$ Elvie Loho
}

\author{
${ }^{1}$ Kandidat Skripsi Fakultas Kedokteran Universitas Sam Ratulangi manado \\ ${ }^{2}$ Bagian Radiologi Fakultas Kedokteran Universitas Sam Ratulangi Manado \\ Email:punkd_dead09@yahoo.com
}

\begin{abstract}
Headache is one of the most complaints in clinical practices. CT Scan is needed as second diagnostic tool to patients who came with headache complaint. CT Scan is able to give the clear picture if there is a intracranial lesions, so it helps the doctor to determine the diagnosis of the patient, because there are so many disease that caused headache. The purpose of this research is to figure out the result of the CT Scan picture of the headache patient at the Department of Radiology BLU RSUP Prof. Dr. R. D. Kandou Manado period of January 1st to December 31st 2011. This research is retrospective descriptive research with the use of secondary data which is the medical record that accessible at the Department of Radiology BLU RSUP Prof. Dr. R. D. Kandou Manado period of January 1st to December 31st 2011. From the whole result of the CT scan examination from 189 people who suffer headache, 76,19\% patients show the normal picture of their heads and $23,81 \%$ patients show abnormality picture of their heads, $57.78 \%$ headache patients are women, $40 \%$ headache patients are adults in the range of ages 41 to 65, and the most CT Scan abnormal picture shows by the patients of cerebral infarct $26.67 \%$. Patient who came with suspicious complaints such as severe, chronic, and repeatable headache will be better if the causes can be determined with the use of head CT Scan, to help to diagnose and prevent the cause of the headache to be more severe.
\end{abstract}

Keywords: Head CT Scan, Headache.

\begin{abstract}
Abstrak: Nyeri kepala merupakan salah satu keluhan yang paling sering ditemukan dalam praktek klinis sehari-hari. CT Scan diperlukan sebagai penunjang diagnostik pada pasien yang datang dengan keluhan nyeri kepala. CT Scan dapat memberikan gambaran yang jelas apabila terdapat kelainan intrakranial, sehingga mempermudah dokter untuk menentukan diagnosis pasien, mengingat sangat beragamnya penyakit yang dapat menyebabkan nyeri kepala. Tujuan penelitian ini untuk mengetahui gambaran hasil CT Scan kepala pada penderita nyeri kepala di bagian Radiologi BLU RSUP Prof. Dr. R. D. Kandou Manado Periode 1 Januari-31 Desember 2011. Penelitian ini merupakan penelitian deskriptif retrospektif dengan memanfaatkan data sekunder berupa catatan medik yang terdapat di bagian Radiologi BLU RSUP Prof. Dr. R. D. Kandou Manado Periode 1 Januari-31 Desember 2011. Keseluruhan hasil pemeriksaan CT Scan kepala berjumlah 189 orang penderita nyeri kepala dan lebih banyak menunjukkan gambaran normal $(76,19 \%)$ dibandingkan gambaran abnormal $(23,81 \%)$, penderita nyeri kepala lebih banyak terjadi pada perempuan (57,78\%), penderita nyeri kepala terbanyak pada kelompok umur dewasa madya 41-65 tahun (40\%) dan gambaran CT Scan abnormal didapatkan terbanyak adalah infark cerebri (26,67\%). Penderita yang datang dengan keluhan nyeri kepala berat, kronik, dan berulang sebaiknya dipastikan penyebabnya melalui pemeriksaan CT Scan kepala. Untuk membantu mendiagnosis, menyingkirkan kemungkinan kelainan intrakranial lainnya dan mencegah memberatnya penyebab nyeri kepala.
\end{abstract}

Kata Kunci: CT Scan Kepala, Nyeri kepala. 
Computed Tomography Scan (CT Scan) merupakan pemeriksaan khusus mutakhir, tidak berbahaya, sederhana, cepat dikerjakan dan banyak memberikan informasi yang dapat diandalkan. ${ }^{1}$ CT Scan dapat memberi gambaran kepala yang sangat jelas tentang proses desak ruang intrakranial, misalnya tumor otak, infark otak, abses otak, hidrosefalus, hematoma epidural, dan hematoma subdural. CT Scan juga dapat memberikan gambaran tentang perdarahan subaraknoidal. CT Scan pada penderita migren, nyeri kepala klaster, nyeri kepala tipe tegang, dan nyeri kepala fungsional akan memberikan gambaran normal. Pada migren yang berat kadang-kadang memperlihatkan area pembengkakan. ${ }^{2}$

Nyeri kepala merupakan salah satu keluhan yang paling sering ditemukan dalam praktek klinis sehari-hari, baik dalam praktek dokter umum, maupun di praktek dokter spesialis. Praktek seorang ahli saraf menemukan $20 \%$ dari penderita yang datang mengeluh tentang nyeri kepala. ${ }^{3}$ Nyeri kepala dipengaruhi oleh beberapa faktor seperti usia, jenis kelamin, genetik, latar belakang sosial ekonomi, dan kultur, serta kerentanan individu. ${ }^{4}$

Suatu penelitian di New York mendapatkan nyeri kepala pada laki-laki sebanyak 22\% dan perempuan $78 \%$. Menurut etnik didapatkan, etnik Kaukasia 44\%, Hispanik 31\%, Afrika-Amerika 12\%, Asia 6\%, dan lain-lain 7\%. Di lain pihak, dari suatu penelitian berbasis populasi di Singapura diperoleh hasil penderita nyeri kepala pada laki-laki $47 \%$ dan perempuan $53 \%$, dengan perbedaan suku: Cina 79\%, Melayu 14\%, India 6\%, dan lain-lain 1\%.

Di Indonesia, dari penelitian di RS Cipto Mangunkusumo Jakarta periode Januari sampai dengan Mei 2006 didapatkan 17,4\% pasien baru dengan keluhan utama nyeri kepala. Khusus untuk nyeri kepala tipe tegang, dari penelitian di RS Kariadi Semarang selama kurun waktu 17 bulan pada tahun 2003 dijumpai 198 pasien dengan nyeri kepala tipe tegang. Persentase nyeri kepala tipe tegang episodik adalah 47,97\% dan tipe kronik 52,03\%. Rasio perempuan dengan laki-laki adalah $5: 4{ }^{6}$
Pemaparan di atas menunjukkan bahwa nyeri kepala merupakan salah satu keluhan yang paling sering ditemukan dalam praktek klinis sehari-hari. CT Scan diperlukan sebagai penunjang diagnostik pada pasien yang datang dengan keluhan nyeri kepala. Karena dapat memberikan gambaran yang jelas apabila terdapat kelainan intrakranial, sehingga mempermudah dokter untuk menentukan diagnosis pasien, mengingat sangat beragamnya penyakit yang dapat menyebabkan nyeri kepala.

Berdasarkan keadaan yang telah dipaparkan di atas, maka penulis tertarik untuk melakukan penelitian tentang gambaran hasil CT Scan pada penderita nyeri kepala di bagian Radiologi FK. UNSRAT/SMF Radiologi BLU RSUP Prof. Dr. R. D. Kandou Manado periode 1 Januari-31 Desember 2011.

\section{Rumusan masalah}

Bagaimana gambaran hasil CT Scan kepala pada penderita nyeri kepala di bagian Radiologi FK UNSRAT/SMF Radiologi BLU RSUP Prof. Dr. R. D. Kandou Manado Periode 1 Januari-31 Desember 2011?

\section{Tujuan penelitian}

Untuk mengetahui gambaran hasil CT Scan kepala pada penderita nyeri kepala di bagian Radiologi FK UNSRAT/SMF Radiologi BLU RSUP Prof. Dr. R. D. Kandou Manado Periode 1 Januari-31 Desember 2011.

\section{METODE PENELITIAN}

Desain penelitian ini merupakan penelitian deskriptif retrospektif dengan memanfaatkan data sekunder berupa catatan medik yang terdapat di bagian Radiologi BLU RSUP Prof. Dr. R. D. Kandou. Waktu penelitian berlangsung dari bulan November-Desember 2012.

\section{Populasi dan sampel}

Populasi pada penelitian ini yaitu semua lembaran permintaan dan bacaan CT Scan kepala di Bagian Radiologi BLU 
RSUP Prof. Dr. R. D. Kandou Manado Periode 1 Januari-31 Desember 2011, sedangkan sampelnya semua lembaran permintaan dan bacaan CT Scan kepala penderita Nyeri Kepala di bagian Radiologi BLU RSUP Prof. Dr. R. D. Kandou Manado Periode 1 Januari-31 Desember 2011.

\section{Variabel penelitian}

Variabel penelitian yang diteliti yaitu hasil pemeriksaan CT scan, jenis kelamin, umur, dan gambaran hasil CT Scan kepala abnormal.

\section{Definisi operasional}

1. Hasil pemeriksaan CT Scan kepala dinyatakan dalam gambaran normal dan abnormal.

2. Jenis kelamin terbagi atas laki-laki dan perempuan.

3. Umur dapat dibagi dalam kelompok umur menurut Hurlock (2001): Anakanak ( $<12$ tahun), Remaja (12-17 tahun), Dewasa awal (18-40 tahun), Dewasa madya (41-65 tahun), dan Dewasa lanjut (>65 tahun).

4. Gambaran hasil CT Scan kepala abnormal pada penderita nyeri kepala dikelompokkan menjadi: Atrofi serebri, Hidrosefalus, Hiperostosis, Infark serebri, Kista serebri, Mastoiditis, Mega sisterna magna, Neoplasma intrakranial, Peradangan intrakranial, Perdarahan intrakranial, dan Ventrikulomegali.

\section{Alat dan bahan}

Alat dan bahan yang digunakan dalam penelitian ini berupa buku-buku teks, Ebook, jurnal, alat tulis menulis, laptop dengan perangkat lunak Ms. Word dan Ms. Excel, alat cetak dan penyimpan data, dan lembaran permintaan dan bacaan CT Scan kepala penderita nyeri kepala di bagian Radiologi BLU RSUP Prof. Dr. R. D. Kandou Manado Periode 1 Januari-31 Desember 2011.

\section{Cara kerja}

Data sekunder dikumpulkan secara retrospektif dari lembaran permintaan dan bacaan CT Scan penderita nyeri kepala di bagian Radiologi BLU RSUP Prof. Dr. R. D. Kandou Manado, dalam kurun 1 tahun, dari 1 Januari-31 Desember 2011. Data yang terkumpul kemudian diolah dan disajikan dalam bentuk tabel (dalam persentase)

\section{HASIL PENELITIAN}

Berdasarkan hasil pengumpulan data sekunder yang dilakukan secara retrospektif di Bagian Radiologi FK UNSRAT/SMF Radiologi BLU RSUP Prof. Dr. R. D. Kandou Manado pada penderita nyeri kepala yang dilakukan pemeriksaan CT Scan selama periode 1 Januari-31 Desember 2011 ditemukan 189 kasus.

\section{Distribusi penderita nyeri kepala berdasarkan hasil pemeriksaan CT Scan}

Dari 189 kasus nyeri kepala yg terjadi pada periode 1 Januari-31 Desember 2011, ditemukan sebanyak 144 kasus (76,19\%) dengan gambaran CT Scan normal dan 45 kasus (23,81\%) dengan gambaran CT Scan Abnormal.

Tabel 1. Distribusi sampel berdasarkan hasil pemeriksaan CT Scan

\begin{tabular}{ccc}
\hline $\begin{array}{c}\text { Hasil } \\
\text { Pemeriksaan } \\
\text { CT Scan }\end{array}$ & n & \% \\
\hline $\begin{array}{c}\text { Gambaran } \\
\text { Normal } \\
\text { Gambaran } \\
\text { Abnormal }\end{array}$ & 144 & 76,19 \\
\hline Jumlah & 45 & 23,81 \\
\hline
\end{tabular}

\section{Distribusi penderita nyeri berdasarkan jenis kelamin}

Dari 45 kasus nyeri kepala yang mempunyai gambaran CT Scan abnormal yang terjadi pada periode 1 Januari-31 Desember 2011, ditemukan penderita laki-laki berjumlah 19 orang $(42,22 \%)$ dan penderita perempuan berjumlah 26 orang $(57,78 \%)$. 
Tabel 2. Distribusi sampel berdasarkan jenis kelamin

\begin{tabular}{ccc}
\hline Jenis Kelamin & $\mathbf{n}$ & $\mathbf{\%}$ \\
\hline Laki - laki & 15 & 42,22 \\
Perempuan & 30 & 57,78 \\
\hline Jumlah & 45 & 100 \\
\hline
\end{tabular}

\section{Distribusi penderita nyeri berdasarkan kelompok umur}

Dari 45 kasus nyeri kepala yang mempunyai gambaran CT Scan abnormal yang terjadi pada periode 1 Januari-31 Desember 2011, terdapat 1 orang penderita (2,22\%) pada kelompok umur anak-anak ( $<12$ tahun), 5 orang penderita $(11,11 \%)$ pada kelompok umur remaja (12-17 tahun), 15 orang penderita (33,33\%) pada kelompok umur dewasa awal (18-40 tahun), 18 orang penderita (40\%) pada kelompok umur dewasa madya (41-65 tahun), dan 6 orang penderita $(13,33 \%)$ pada kelompok umur dewasa lanjut (>65tahun).

Tabel 3. Distribusi sampel berdasarkan kelompok umur

\begin{tabular}{lcc}
\hline \multicolumn{1}{c}{ Umur } & n & \% \\
\hline Anak-anak (<12 tahun) & 1 & 2,22 \\
Remaja (12-17 tahun) & 5 & 11,11 \\
Dewasa awal (18-40 tahun) & 15 & 33,33 \\
Dewasa madya (41-65 tahun) & 18 & 40 \\
Dewasa lanjut (>65 tahun) & 6 & 13,33 \\
\hline Jumlah & 45 & 100 \\
\hline
\end{tabular}

\section{Distribusi penderita nyeri kepala berdasarkan gambaran CT Scan kepala abnormal}

Dari 45 kasus nyeri kepala, gambaran CT Scan kepala yang abnormal ditemukan 6 orang penderita ( $13,33 \%$ ) dengan gambaran atrofi cerebri, 4 orang penderita (8,89\%) dengan gambaran hidrosefalus, 1 orang penderita (2,22\%) dengan gambaran hiperostosis, 12 orang penderita (26,67\%) dengan gambaran infark cerebri, 3 orang penderita (6,67\%) dengan gambaran kista cerebri, 2 orang penderita (4,44\%) dengan gambaran mastoiditis, 1 orang penderita dengan gambaran mega cisterna magna, 10 orang penderita $(22,22 \%)$ dengan gambaran neoplasma intrakranial, 2 orang penderita $(2,22 \%)$ dengan gambaran peradangan intrakranial, 3 orang penderita (6,67\%) dengan gambaran perdarahan intrakranial, dan 1 orang penderita (2,22\%) dengan gambaran ventrikulomegali.

Tabel 4. Distribusi sampel berdasarkan gambaran CT Scan kepala abnormal

\begin{tabular}{lcc}
\hline $\begin{array}{l}\text { Hasil Pemeriksaan } \\
\text { CT Scan }\end{array}$ & n & \% \\
\hline Atrofi cerebri & 6 & 13,33 \\
Hidrosefalus & 4 & 8,90 \\
Hiperostosis & 1 & 2,22 \\
Infark cerebri & 12 & 26,67 \\
Kista cerebri & 3 & 6,67 \\
Mastoiditis & 2 & 4,44 \\
Mega cisterna magna & 1 & 2,22 \\
Neoplasma intrakranial & 10 & 22,22 \\
Peradangan intrakranial & 2 & 4,44 \\
Perdarahan intrakranial & 3 & 6,67 \\
Ventrikulomegali & 1 & 2,22 \\
\hline Jumlah & 45 & 100 \\
\hline
\end{tabular}

\section{PEMBAHASAN}

Pada penelitian ini ditemukan sebanyak 189 kasus nyeri kepala yang melakukan pemeriksaan CT Scan di Bagian Radiologi FK UNSRAT/SMF Radiologi BLU RSUP Prof. Dr. R. D Kandou Manado selama periode 1 Januari-31 Desember 2011.

\section{Berdasarkan hasil pemeriksaan CT scan kepala}

Didapatkan jumlah penderita nyeri kepala yang mempunyai gambaran CT Scan normal lebih banyak yaitu sebanyak 144 orang (76,19\%) dari 189 orang yang 
melakukan pemeriksaan CT Scan kepala. Sedangkan sisanya sebanyak 45 orang $(23,81 \%)$ mempunyai gambaran CT Scan abnormal. CT Scan pada penderita nyeri kepala primer seperti nyeri kepala tipe tegang, klaster dan migren akan memberikan gambaran yang normal. Sedangkan pada nyeri kepala sekunder CT scan dapat memberi gambaran yang sangat jelas tentang kelainan proses desak ruang intrakranial. $^{2}$ Sebuah penelitian dari Minnesota, amerika serikat tahun 2004 menenemukan nyeri kepala primer lebih sering terjadi dibandingkan nyeri kepala sekunder. Hal ini disebabkan faktor penyebab nyeri kepala yang paling sering adalah stress dan tekanan mental. ${ }^{8}$

\section{Berdasarkan jenis kelamin}

Didapatkan penderita terbanyak pada perempuan yaitu 26 orang (57,78\%), sedangkan pada laki-laki sebanyak 19 orang (42,22\%). Hal ini tidak berbeda jauh dengan penelitian yang dilakukan di Amerika Serikat yang mendapatkan sekitar 28 juta penderita nyeri kepala, dimana $2 / 3$ nya adalah perempuan dan $1 / 3$ nya adalah pria. ${ }^{9}$ Penelitian lainya yang dilakukan di singapura menemukan distribusi penderita nyeri kepala pada laki-laki sebanyak $47 \%$ dan perempuan 53\%. ${ }^{5}$ Menurut kepustakaan yang ada, nyeri kepala memang lebih sering terjadi pada perempuan dibandingkan lakilaki dengan rasio perbedaan 5:4. ${ }^{6}$ Hal ini disebabkan karena perubahan kadar hormon estrogen dan progesteron yang berperan penting dalam siklus menstruasi dan kehamilan pada perempuan. Selama siklus menstruasi normal, kadar hormon estrogen menurun dengan cepat pada fase luteal akhir. Penurunan ini mempengaruhi zat-zat kimia di otak, salah satunya adalah serotonin yang berperan mengendalikan rasa nyeri. Kekurangan serotonin akan menyebabkan menyempitnya pembuluh darah otak dan menyebabkan serangan nyeri kepala. ${ }^{10}$

\section{Berdasarkan kelompok umur}

Didapatkan jumlah penderita terbanyak pada kelompok umur dewasa madya (41-65 tahun) yaitu 18 orang (40\%), kemudian dewasa awal (18-40 tahun) sebanyak 15 orang (33,3\%), dewasa lanjut (>65tahun) sebanyak 6 orang $(13,4 \%)$, remaja (12-17 tahun) sebanyak 5 orang $(11,1 \%)$ dan yang paling sedikit anak-anak ( $<12$ tahun) yaitu sebanyak 1 orang (2,2\%). Menurut penelitian di RSUP.H.Adam Malik Medan selama periode 27 Desember 2006-31 Maret 2007 menunjukkan penderita nyeri kepala paling banyak pada kelompok umur 41-50 tahun yaitu 48,57\% dan 51-60 tahun 28,57\%. ${ }^{9}$ Hal ini juga sesuai dengan kepustakaan yang menuliskan bahwa pada usia pertengahan atau middle age 45-59 tahun merupakan kelompok umur yang paling rentan mengalami nyeri kepala. ${ }^{6}$ Usia pertengahan merupakan masa transisi, dimana pria dan wanita meninggalkan ciriciri jasmani dan prilaku masa dewasanya dan memasuki suatu periode dalam kehidupan dengan ciri-ciri jasmani dan prilaku yang baru. Sering pada usia ini seseorang menjadi stress karena penyesuaian secara radikal pada pola hidup yang disertai dengan perubahan fungsi fisik dan kemampuan ingatan akan berdampak pada sulitnya penyesuaian diri sehingga menyebabkan stress pada individu. ${ }^{11}$ Sedangkan faktor penyebab nyeri kepala yang paling sering adalah stress dan tekanan mental. $^{8}$

\section{Berdasarkan hasil gambaran CT scan abnormal}

Didapatkan hasil gambaran CT Scan Abnormal terbanyak adalah infark cerebri dengan 12 gambaran (26,67\%), diikuti dengan gambaran neoplasma intrakranial dengan 10 gambaran $(22,22)$, atrofi cerebri dengan 6 gambaran $(13,33 \%)$, hidrosefalus dengan 4 gambaran (8,89\%), gambaran kista cerebri 3 gambaran $(6,67 \%)$, perdarahan intrakranial 3 gambaran (6,67\%), mastoiditis 2 gambaran $(4,44 \%)$, peradangan intrakranial 2 gambaran (4,44\%), ventrikulomegali 1 gambaran (2,22\%), mega cisterna magna 1 gambaran $(2,22 \%)$, dan hiperostosis 1 gambaran (2,22\%). Hal ini sesuai dengan kepustakaan yang menyatakan bahwa, CT scan dapat memberi gambaran 
yang sangat jelas tentang proses desak ruang intrakranial, misalnya tumor otak, infark otak, hematoma (intraserebral, subdural, dan epidural) abses otak, dan hidrosefalus. ${ }^{2}$

\section{SIMPULAN}

Berdasarkan hasil penelitian yang dilakukan di bagian Radiologi FK UNSRAT/SMF Radiologi BLU RSUP Prof. dr. R. D. Kandou Manado Periode 1 Januari31 Desember 2011 mengenai gambaran CT Scan kepala pada penderita nyeri kepala, dapat disimpulkan bahwa:

1. Hasil pemeriksaan CT Scan kepala penderita nyeri kepala lebih banyak menunjukkan gambaran normal (76,19\%).

2. Penderita nyeri kepala lebih banyak terjadi pada perempuan (57,78\%).

3. Penderita nyeri kepala terbanyak pada kelompok umur dewasa madya 41-65 tahun (40\%).

4. Dari 189 penderita nyeri kepala terdapat 45 penderita dengan gambaran hasil CT Scan kepala abnormal. Dari hasil gambaran CT Scan abnormal didapatkan terbanyak adalah infark cerebri dengan 12 gambaran $(26,67 \%)$, gambaran neoplasma intrakranial dengan 10 gambaran $(22,22)$, atrofi cerebri dengan 6 gambaran (13,33\%), hidrosefalus dengan 4 gambaran $(8,89 \%)$, gambaran kista cerebri 3 gambaran (6,67\%), perdarahan intrakranial 3 gambaran (6,67\%), mastoiditis 2 gambaran (4,44\%), peradangan intrakranial 2 gambaran $(4,44 \%)$, ventrikulomegali 1 gambaran (2,22\%), mega cisterna magna 1 gambaran $(2,22 \%)$, dan hiperostosis 1 gambaran (2,22\%).

\section{SARAN}

1. Perlunya upaya pencegahan terhadap stress dan tekanan mental dengan lebih banyak relaksasi, berlibur dan mendekatkan diri pada tuhan, sehingga dapat mencegah terjadinya nyeri kepala.

2. Sebaiknya penderita yang datang dengan keluhan nyeri kepala berat, kronik, dan berulang dipastikan penyebabnya melalui pemeriksaan CT Scan kepala untuk membantu mendiagnosis, menyingkirkan kemungkinan kelainan intrakranial lainnya dan mencegah memberatnya penyebab nyeri kepala.

\section{UCAPAN TERIMA KASIH}

Terima kasih kepada dr. Rizal Tumewah, SpS sebagai penguji 1 dan dr. D. H. C. Pangemanan, MKes, AIFM sebagai penguji 2 atas masukan dan saran dan kepada pihak-pihak yang secara langsung ataupun tidak langsung memberikan gagasan dan ide kepada penulis.

\section{DAFTAR PUSTAKA}

1. Mardjono M, Sidharta P. Neurologi klinis dasar. Jakarta: Dian Rakyat, 2008; P.472.

2. Harsono. Buku Ajar Neurologi Klinis Dasar. Yogyakarta: Gadjah Mada University Press, 2011; P.282.

3. Chandra B. Nyeri kepala. In: Markam S, Harahap TP, Sastrodiwirjo S, Kusumoputro S, editors. Penuntun Neurologi. Tangerang: Binarupa Aksara, 2010; p.194.

4. National institute of neurogical disorder. Headache. 30 November 2011 [diakses 2 november 2012]. Diunduh dari: http://www.ninds.nih.gov/disorders/headach e/headache.htm.

5. Suroto. Nyeri Kepala di Indonesia \& klasifikasi Nyeri Kepala menurut IHS (International Headache Society). In: Sjahrir $\mathrm{H}$, editor. Nyeri Kepala 1. Medan: USU Press, 2004; p.1-26.

6. Sherwood L. Human Physiology From Cells to Systems (Edisi ke-7). Belmont: Brooks/Cole, 2008; p.155-7.

7. Pearce JMS. Headache. Journal of neurology, neurosurgery, and psychiatry. 2004;57:134-43.

8. Nasution IK, Aldy S. Rambe, Sjahrir H. Gangguan memori pada penderita nyeri kepala primer kronik. Majalah kedokteran nusantara. 2007;40:254-7.

9. Robbins Headache Clinic. Hormones and Headaches. 15 Januari 2012 [di akses 18 Januari 2013]. Di unduh dari: www.headachedrugs.com/pdf/hormones.pdf

10. Hurlock, Elizabeth B. Developmental Psychology: A Life Span Approach. London: TJ International; 2009. 